\title{
Методы повышения чувствительности многорядных фотоприемных устройств для регистрации малоразмерных объектов
}

\author{
К.В. Козлов ${ }^{1,2)}$, В.А. Стрельцов ${ }^{1,2)}$, Б.Н. Дражников ${ }^{1)}$, Я.С. Бычковский ${ }^{1)}$ \\ ${ }^{1}$ АО «НПО «Орион», Москва, 111538, Косинская, 9 \\ ${ }^{2}$ МФТИ, Москва, 117303, ул. Керченская, д. 1А, корп. 1 \\ тел:+7 (917) 582-3460, факс:+7 (499) 373-6862, эл.nочта: kozlov.k.v@ mail.ru
}

DOI 10.34077/RCSP2019-63

Современные инфракрасные (ИК) фотоприемные устройства (ФПУ) с режимом временной задержки и накопления (BЗН) широко применяются для решения задач регистрации слабых оптических сигналов [1-3]. Сканирующие ВЗН-матрицы позволяют достичь высокой равномерности пеленгационной характеристики при регистрации малоразмерных объектов, повысить отношение сигнал/шум на выходе прибора, снизить требования к дефектности фоточувствительного материала. Каскадирование отдельных фотоприемных модулей $(\Phi М)$ на общем основании внутри ФПУ при работе в режиме сканирования позволяет достичь форматов ИК-изображений, больших 10000х10000 элементов разложения.

Одной из основных задач, решаемых многорядными ИК ФПУ, является регистрация малоразмерных объектов. Малоразмерными считаются объекты, размер изображения которых в плоскости фоточувствительного слоя соизмерим с размером фоточувствительного элемента (ФЧЭ) и определяется преимущественно функцией рассеяния точки (ФРТ) оптической системы (ОС). Для таких многорядных ИК ФПУ важнейшими параметрами являются вольтовая и пороговая чувствительность при регистрации малоразмерных объектов, чему и посвящен доклад.

В докладе рассматриваются методы коррекции амплитудно-частотной характеристики (АЧХ) образца многорядного ИК ФПУ на основе прямой буфферной инжекции при низких уровнях фонового излучения. Предложены и проверены экспериментально дискретно-аналоговые фильтры, реализуемые внутри большой интегральной схемы (БИС) считывания и, помимо коррекции АЧХ, улучшающие чувствительность ФПУ при регистрации малоразмерных объектов.

Также предложен дискретно-аналоговый фильтр, реализуемый в БИС, позволяющий снизить ресурсоемкость цифровой обработки сигналов ФПУ и улучшить чувствительность при регистрации малоразмерных объектов.

Приведено сравнение результатов высокочастотной фильтрации сигналов (для устранения малоинформативной фоновой составляющей) внутри БИС ФПУ и при обработке в цифровом виде.

Представлены результаты экспериментального исследования фотоэлектрических параметров многорядного ФПУ при различных размерах ФЧЭ. Определены рациональные размеры ФЧЭ для решения задачи регистрации малоразмерных объектов. Определены основные факторы ограничивающие шумы ФПУ. Намечены пути дальнейшего улучшения чувствительности ИК ФПУ.

\section{Jumepamypa}

[1] Козлов К.В. и др. // Успехи прикладной физики. 2017. Т. 5. № 5. С. 466-480.

[2] Козлов К.В., Кузнецов П.А. // Прикладная физика. 2015. № 3. С. 61-66.

[3] М.А. Тришенков Фотоприемные устройства и ПЗС. Обнаружение слабых оптических сигналов. -

М.: Радио и связь, 1992. 